原著

成人鼠径ヘルニアの Nyhus 分類による病態別術式選択法の検討

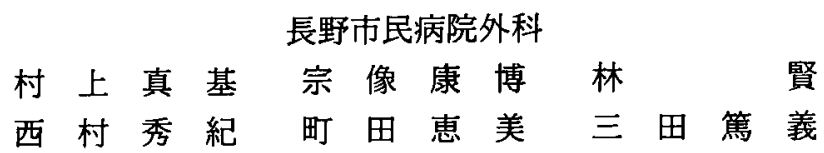

1995年 6 月から1997年 8 月までに行った成人鼠径へルニア手術一従来法, Mesh Plug 法, 腹腔鏡下法に対し Nyhus 分類別に検討した. Type-I, II 症例では術後入院期間, 術 後鎮痛剤使用回数の術式間較差は少なく, Type-1II 症例では入院期間, 鎮痛剂使用回数 で従来法の成績が悪く tension repair の短所が目立った. 各術式には長短所があり病態, QOL に従った症例毎の術式選択が必要である.すなわち Type-I では腹壁補強の必要は なく従来法を行う.Type-II では若年者には人工物の使用を控えた従来法を行うが， Type-III との鑑別が難しい場合は Meshによる補強を行う. Type-III は Mesh による修 復の適応で, Plug 法は成績良好であるが, 巨大へルニアには大きな Mesh を用いる腹腔 鏡下法が適応となる. Type-IV 症例のうち, 前方アプローチ後の再発例には腹腔鏡下法 を行う。この Nyhus 分類による術式選択法を採用することにより, 術後の成績は改善さ れた。

索引用語: 臼径へルニア, 従来法, Mesh Plug 法, 腹腔鏡下手術, 病態別術式選択法

\section{緒 言}

鼠径ヘルニアは外科医が最もよく遭遇する疾患のひ とつである.成人鼠径ヘルニアに対する手術は約 100 年 前にBassini”により提唱された後壁補強術式をもと にして，長くその基本は変わらなかった. 近年になり メッシュを用いた tension-free 術式の概念が生じ2), Lichtenstein と Shore ${ }^{3)}$ が1974年にヘルニア門に傘状 のメッシュを挿入する Plug 法を報告, 1990年には Ger ら ${ }^{4}$ が腹腔鏡下へルニア修復術を報告しへルニア に対する治療法が大きく変わりつつある. われわれは 自験例加従来法, Mesh Plug 法, 腹腔鏡下法を比較 し, ヘルニアの病態に応じた術式選択法を検討した。

\section{対象と方法}

1995年 6 月から1997年 8 月までの 2 年 3 力月間に行 われた成人鼠径へルニアの手術を対象とした。術式は 従来法 (Conventional hernia repair), Mesh Plug 法 (Mesh Plug hernia repair, 以下 Plug 法), 腹腔鏡下 法 (Laparoscopic hernia repair, 以下鏡視下法) の いずれかを選択し患者に informed consent を得て決 定した。

1998年 1 月 5 日受付 1998 年 9 月 3 日採用
術前に視触診て Nyhus 分類（表 1 1 $^{51}$ によ Typing を行い, 手術所見により術後に Type を確定した.

従来法はBassini 原法”，または McVay 法6), Iliopubic tract repair 法")とし,ヘルニア亯高位結禁の 後, 腹横筋腱膜, 横筋筋膜を鼠径勒帯, Cooper 靯带, iliopubic tract 等に繾合固定し後壁補強するとともに 内鼠径輪を縫縮した. 麻酔は原則として脊椎麻酔とし た. Plug 法は Rutkow と Robbins ${ }^{8}$ の術式に準じて行 い, 精索および hernia sac を剝晟, 大きな sac 以外は sacの切開や結禁を行わずにヘルニア門へ反転し, 全 例 Bard ${ }^{\circledR}$ Marlex ${ }^{\circledR}$ Mesh PerFix Plug を使用して plug をへルニア門へ挿入, 付属の preshaped onlay patch を留置した. 手術は硬膜外麻酔あるいは春椎麻 酔下に行った. 鏡視下法は経腹的法 (Transabdominal preperitoneal repair, 以下 TAPP) 99 るいは腹膜外 法 (Totally extraperitoneal preperitoneal repair, 以下 TEP) ${ }^{10)}$ とし, トラカールは 3 箇所に挿入, hernia $\mathrm{sac}$ の大きな症例では sacを切離して豩離, 小さい場 合は全て剥離した. $13 \times 8 \mathrm{~cm}$ の Prolene ${ }^{\circledR}$ mesh にス リットをいれて用い, 外鼠径, 内鼠径, 大腿の 3 箇所 のヘルニア発生部位全体を被覆するようにヘルニアス テイプラーで固定した. TAPPや再発例で腹膜を広く 
表 1 Nyhus による鼠径ヘルニア分類(文姑 5 より引用)

\begin{tabular}{|c|c|}
\hline & Nyhus LM, 1991 \\
\hline \multicolumn{2}{|c|}{ Type I : indirect inguinal hernia } \\
\hline \multicolumn{2}{|c|}{ Internal inguinal ring normal (e.g., pediatric hernia) } \\
\hline \multicolumn{2}{|r|}{ Type II : indirect inguinal hernia } \\
\hline \multicolumn{2}{|c|}{$\begin{array}{l}\text { Internal inguinal ring dilated but posterior inguinal wall intact } \\
\text { inferior deep epigastric vessels not displaced }\end{array}$} \\
\hline \multirow[t]{5}{*}{ Type III : } & posterior wall defects \\
\hline & Direct inguinal hernia (IIIa) \\
\hline & Indirect inguinal hernia (IIIb) \\
\hline & $\begin{array}{l}\text { Internal inguinal ring dilated, medially encroaching on or } \\
\text { destroying the transversalis fascia of the Hesselbach triangle } \\
\text { (e.g., massive scrotal, sliding, or pantaloon hernias) }\end{array}$ \\
\hline & Femoral hernia (IIlc) \\
\hline \multirow[t]{5}{*}{ Type IV : } & recurrent hernias \\
\hline & Direct \\
\hline & Indirect \\
\hline & Femoral \\
\hline & Combined \\
\hline
\end{tabular}

剥離しなかった症例には meshのサイズを小さくして 使用した。麻醉は全身麻酔とした。

症例毎の手術時間, 術後入院期間, 術後鎮痛剤使用 回数，合併症の有無を調べた。また1997年 9 月から 10 月にかけて電話によるアンケートを行い, ヘルニア再 発の有無, 治療に対する満足度等を聴取し, 各術式の 特徵について検討した。

なお術後の鎮痛剛は患者の要求に応じて投与し, 使 用薬㘊は diclofenac sodium (ボルタレン坐薬), pentazocine (ソセゴン注), buprenorphine hydrochloride (レペタン注), hydroxyzine(アタラックス P 注)の中 から医師が選択した。また退院は医師が許可した上で, 患者が退院日を決定した。

合併症は術中, 術後に手術, 気腹操作に起因して生 じ，処置を要したものとし，再発もこれに含めた，全 身疾患として術前より認めていた合併症（不整脈，心 不全, 精神分裂病など) は除き，また処置を要さない 皮下気腫, 血腫槳液腫等は除外した。

統計学的検討は $\mathrm{t}$ 検定により $\mathrm{p}<0.05$ を有意差あり とした.

\section{結 果}

手術症例は150例166病巣であり全症例の平均年齢は 60.7 歳 (17〜94歳)で術式間に差はなく, 男女比117： 33であった。術後診断は Nyhus 分類 Type-I： 5 病巣, II $: 19$ 病巣, IIIa $: 37$ 病巣, IIIb $: 66$ 病巣, IIIc $: 14$ 病 巣, IV：25病巣であった。術式別では従来法は Bassini 法を 6 例, McVay 法を15例, Iliopubic tract repair 法
を 3 例に行った. Plug 法は41例42病巣に行った. 鏡視 下法は TAPP を62例75病宩, TEP を23例25病单に 行った (表 2).

両側例16例のうち 1 例は Plug 法で行い, 他の15例 は鏡視下法で行った. Type-IV の21例25病巣は従来法 術後18例, Plug 法術後 2 例, 鏡視下法術後 1 例であり, 全例鏡視下法を行った. Plug 法は材料購入の都合上, 40番目の症例より導入した．嵌頓へルニア等の緊急症 例 5 例は，感染の恐れがあったため mesh を用いない 従来法を行った。

他の手術（胃全摘術, 人工肛門閉鎖術, 腹腔鏡下胆 亳摘出術, 内視鏡的前立腺切除術, 高位除辠術, 尿管 切石術）と同時に行った症例の手術時間, 術後入院期 間，鎮痛剤使用回数は集計より除外した。

片側例での平均手術時間は従来法50.0分, Plug 法 40.8分に対し, 鏡視下法は78.9分と有意に長かった $(\mathrm{p}<0.001)$.

平均術後入院期間は従来法8.5日, Plug 法5.2日, 鏡 視下法6.0日であり，従来法が他の 2 法に対し有意に長 かった $(\mathrm{p}<0.001)$. Plug 法と鏡視下法の間に有意差は 認めなかった。

平均鎮痛剛使用回数は従来法2.0回, Plug 法0.5回, 鏡視下法1.6回であり, Plug 法は他の 2 法に対し有意 に少なかった(従来法に対し $\mathrm{p}<0.001$, 鏡視下法に対 ᄂ $\mathbf{p}<0.01)$.

合併症は 7 例 (4.7\%) に認めた。従来法の 1 例は弁 置換術後の warfarin（ワーファリン）服用患者に生じ 
表 2 術式別の症例内訳と成絴

\begin{tabular}{|c|c|c|c|c|c|}
\hline & & 従来法 & Mesh Plug 法 & 腹腔鏡下法 & 合計 \\
\hline 症例数 & & 24 & 41 & 85 & 150 \\
\hline 病笨数 & & 24 & 42 & 100 & 166 \\
\hline 男女比 & & $14: 10$ & $35: 6$ & $68: 17$ & $117: 33$ \\
\hline 平均年龄 (歳) & & $58.3(25-94)$ & $61.0(19-77)$ & $61.2(17-85)$ & $60.7(17-94)$ \\
\hline \multirow[t]{6}{*}{ Nyhus 分類別病栄数 } & 1 & 2 & 0 & 3 & 5 \\
\hline & II & 4 & 9 & 6 & 19 \\
\hline & IIla & 3 & 10 & 24 & 37 \\
\hline & IIIb & 10 & 20 & 36 & 66 \\
\hline & IIlc & 5 & 3 & 6 & 14 \\
\hline & IV & 0 & 0 & 25 & 25 \\
\hline \multicolumn{2}{|l|}{ 術式 (病巣数) } & $\begin{array}{c}\text { Bassini : } 6 \\
\text { McVay : } 15 \\
\text { IPT-repair : } 3\end{array}$ & Mesh Plug: 42 & $\begin{array}{l}\text { TAPP }: 75 \\
\text { TEP }: 25\end{array}$ & \\
\hline \multirow[t]{2}{*}{ 平均手術時間(分) } & 片側 & $50.0^{*}(28-130)$ & $40.8^{*}(21-119)$ & $78.9(41-152)$ & \\
\hline & 両側 & $(-)$ & 125(1例のみ) & $118.7(82-185)$ & \\
\hline 合併症 (例数) & & 血腫： 1 & $\begin{array}{c}\text { 再発：1 } \\
\text { 手術不成功：1 }\end{array}$ & $\begin{array}{c}\text { 再発：1 } \\
\text { 膀胱損傷：2 } \\
\text { 大量出血：1 }\end{array}$ & $7(4.7 \%)$ \\
\hline 術後平均入院期間(日) & & $8.5(4-18)$ & $5.2^{* *}(2-10)$ & $6.0^{* *}(2-11)$ & $6.2(2-18)$ \\
\hline 術後平均鎮痛剂使用回数 & & $2.0(0-7)$ & $0.5^{* * *}(0-2)$ & $1.6(0-14)$ & $1.4(0-14)$ \\
\hline
\end{tabular}

* : 腹腔箕下法に对して有意差あり $\mathrm{p}<0.001$

* : 従来法に対して有意差あり $\mathrm{p}<0.001$

***：従来法に対して $(p<0.001)$ 及び腹腔鏡下法に対して $(p<0.01)$ 有意差あり

IPT-repair : lliopubic tract repair 法

TAPP : Transabdominal preperitoneal repair 法

TEP : Totally extraperitoneal repair 法

た皮下血腫で, 数回の穿刺を要した. Plug 法の手術不 成功 1 例はへルニア門の直径が $4 \mathrm{~cm}$ 以上ある TypeIIIa 症例で, 既製の large plug を 2 個使用してもへル ニア門の閉鎖が不完全でしかも preshaped onlay patchでの後壁被覆も不十分であり，本例は翌日に TEPで再手術を行った。再発の 1 例は内鼠径へルニア 術後約 1 カ月で plug の脇より内豕径ヘルニアが再発 した. 鏡視下法では 4 例に合併症を認めた. 再発 1 例 は内外鼠径へルニアに対するTEPでの外鼠径へルニ ア見落とし例であり術後13日目に再発した。膀胱損傷 2 例は TEP で生じ， 1 例は開腹して損傷部を修復し ヘルニアに対しては McVay 法を行い，1 例は腹腔鏡 下に Linear stapler を用いて補修した. 出血 1 例は下 腹壁動脈損傷により約 $400 \mathrm{ml}$ の出血を認めたが腹腔鏡 下に止血可能であった．合併症には含めていないが TEP での腹膜損傷 1 例は TEP の継続が困難となり TAPPに変更して修復した (再発の有無については電 話アンケートも参照した)。

䖢径管後壁の正常な Type-I および II と後壁の脆弱
な Type-III の術式別成績を比較した(表 3). 手術時間 はいずれも鏡視下法で有意に長くなった。術後入院期 間は Type-I, II で 3 術式とも短縮したが術式間の傾向 は同じであった。Type-III での従来法は入院期間が 9.3日と特に長くなった. 鎮痛剤使用回数は Type-III の従来法で増加し Plug 法では隇少した. Type-I, II の 鎮痛剂使用はいずれも 1 回程度で術式間に差はなかっ た. Bassini 法と McVay 法, Iliopubic tract repair の 間には各項目間に差はなくひとつの術式として扱っ た. TAPP と TEP の比較でも差を認めず,両術式はひ とつの術式として扱った.なお Type-IV は全例鏡視下 法で行い, 片側例での平均手術時間は80.5分, 両側例 をあわせた術後入院期間は 6.9 日, 鎮痛剤使用回数は 1.3回であった.

後述する病態別術式選択法（図 3) を採用する以前 の前期症例 44例と,採用してからの後期106例を入院期 間と鎮痛剤使用で比較検討した (表 4). 前期症例では 入院期間，鎮痛剤使用回数とも成績は悪い傾向にあっ た。後期症例では成績は向上傾向にあった.特に Type- 
表 3 病態別にみた各術式の成績

\begin{tabular}{|c|c|c|c|c|c|c|c|c|c|}
\hline \multirow{2}{*}{ Nyhus 分類 } & \multicolumn{2}{|c|}{ 従来法 } & \multicolumn{2}{|c|}{ Mesh Plug 法 } & \multicolumn{3}{|c|}{ 腹腔鏡下法 } & \multicolumn{2}{|c|}{ 合計 } \\
\hline & I, II & III & I, II & III & I, II & III & IV & I, II & III \\
\hline 症例数 (病巣数) & $6(6)$ & $18(18)$ & $9(9)$ & $32(33)$ & $8(9)$ & $56(66)$ & $21(25)$ & $23(24)$ & $106(117)$ \\
\hline 男女比 & $4: 2$ & $10: 8$ & $7: 2$ & $28: 4$ & $4: 4$ & $44: 12$ & $20: 1$ & $15: 8$ & $82: 24$ \\
\hline 平均年齢：歳 & 34.2 & 66.4 & 47.4 & 64.9 & 42.0 & 64.3 & 60.0 & 42.1 & 64.8 \\
\hline 手術時間：分 片側 & 44.2 & 52.3 & 34.9 & 42.8 & $94.2^{*}$ & $76.4^{*}$ & 80.5 & & \\
\hline 両側 & $(-)$ & $(-)$ & $(-)$ & $(-)$ & 107.5 & 115.3 & 130.4 & & \\
\hline 術後入院期間：日 & $6.5^{* *}$ & $9.3^{* * *}$ & 3.9 & 5.7 & 4.7 & 5.8 & 6.9 & 4.9 & 6.3 \\
\hline 術後鎮痛剂使用回数 & 1.2 & 2.3 & 1.1 & $0.3 \#$ & 1.0 & 1.7 & 1.3 & 1.1 & 1.5 \\
\hline 合併症 & なし & 1 例 & なし & 2 例 & なし & 4 例 & なし & なし & 7 例 \\
\hline
\end{tabular}

* : 従来法に対して $(p<.01)$ 及び Plug 法に対して $(p<.001)$ 有意差あり

**: Plug 法に対して $(p<.01)$ 及び腹腔鏡下法に対して $(p<.05)$ 有意差あり

***: Plug 法に対して $(p<.01)$ 及ひ腹腔鏡下法に対して $(p<.001)$ 有意差あり

\#: 従来法に対して $(\mathrm{p}<.001)$ 及び腹胿鏡下法に対して $(\mathrm{p}<.01)$ 有意差あり

腹腔鏡下法両側例で片側 II, 片側 IIIb あり

表 4 術式選択法考案以前 (前期) と以後(後期)の比較

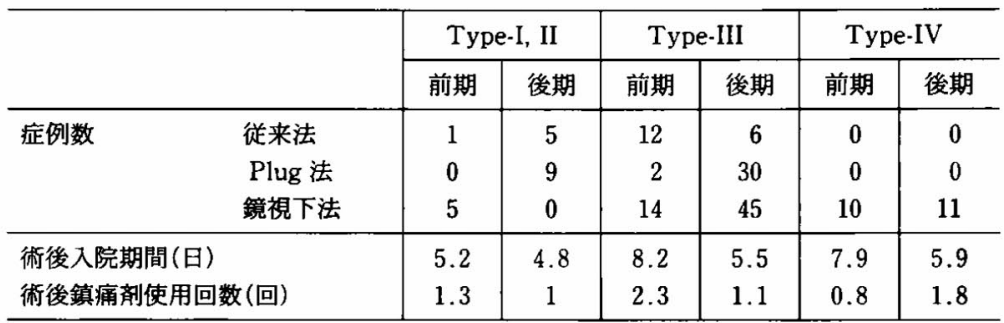

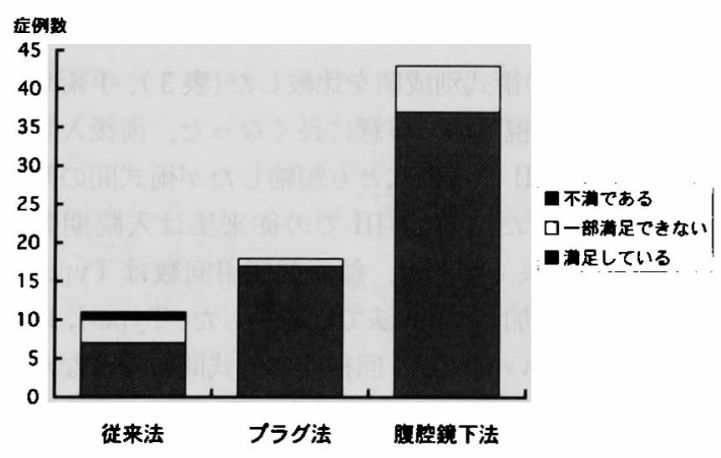

図 1 アンケート調査による治療全般への满足度

III 症例の成績は改善が著しく, 前期と後期との間に入 院期間8.2日および5.5日（ $\mathrm{p}<0.001) ，$ 鎮痛剂使用回数 2.3回および1.1回（p<0.05）と有意差が認められた. 患者への電話アンケートは他の手術を同時に行った 症例や転居等により所在不明となった症例を除いて行 い，80例より回答を得た。手術を含めた治療全般への 満足度は Plug 法抢よび鏡視下法ではほとんど不満が なく，従来法では満足している症例は64\%で，不満を

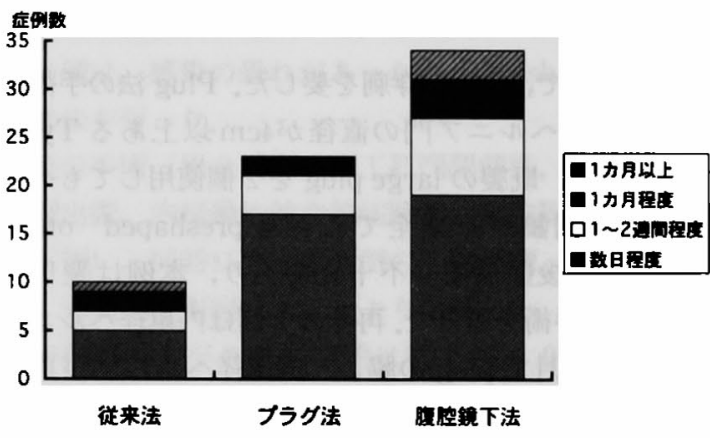

図 2 社会復帰に要する期間

残す症例も存在した（図 1 ).

日常生活, 社会生活への復㷌に要する期間はPlug 法で短い傾向にあり，従来法では長い傾向にありここ の調査結果は術後入院期間と同じ傾向であった（図 2 ).

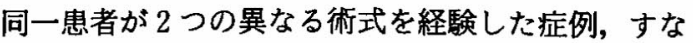
わち Type-IV 症例あるいは反対側でのヘルニア手術 既往例15例で,従来法と鏡視下法を比較してもらった。 


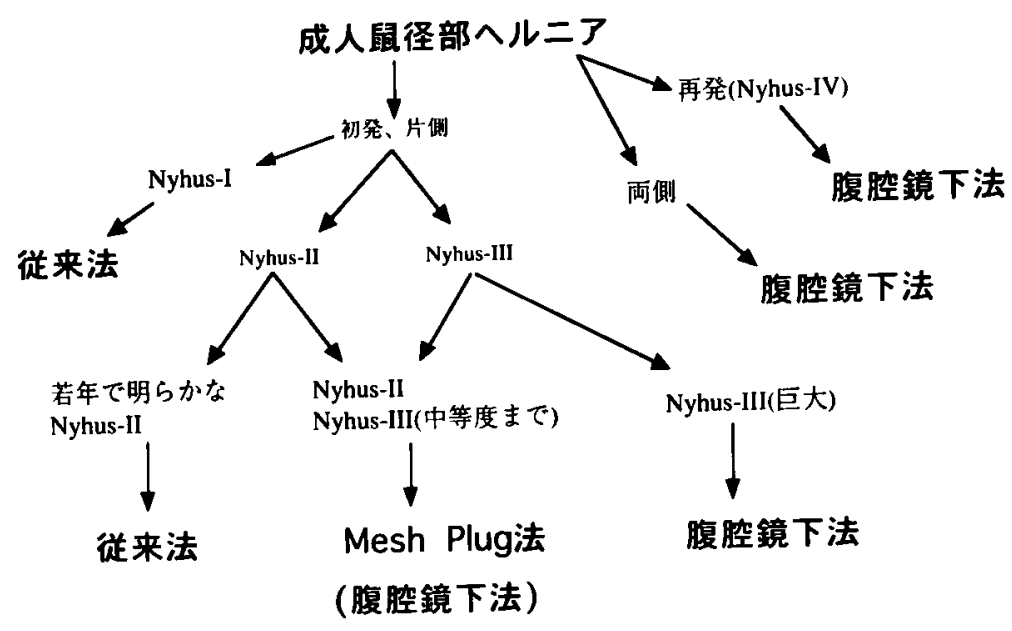

図 3 Nyhus 分類に従った術式選択法

この結果，10例 (67\%) で腹腔鏡下法が良いと評価し， 3 例 (20\%) は同程度としたが，2例（13\%）は従来 法が良かったと評価した。

\section{考察}

今回，われわれの施設を訪れたへルニア患者は本邦 で報告されている平均年齢50～70歳，男性約 8 割とほ ほ同じであっだ”. 鏡視下法の割合が多く，また TypeIV 症例が21例と比較的多いのは, 当科では鏡視下手術 を多数手がけており，腹腔鏡下へルニア修復術を目的 として患者の紹介を受けることが多く，また患者自身 も腹腔鏡下手術を希望して来院することが多いためと 思われた。

全症例の術式別成績をみると，鏡視下法で手術時間 が長いのは他施設の報告と同じであった ${ }^{12)-15) . ~}$ 術者全 員が腹腔鏡下手術に習熟していたと考えられるのにこ のような成績となったのは, 鏡視下法が手術手技に修 練を要し，熟練者でも時間がかかると結論づけて良い と思われた。

術後入院期間と鎮痛剤使用回数は手術による疼痛, つっぱり感の指標のひとつと考えられ, Plug 法はいず れの病態でも疼痛が少なく入院期間も短かった．鎮痛 剤使用はほとんどの症例で 0 ないし 1 回であった。し かし, Plug 法の鎮痛郕使用回数では Type-I, II 症例 1.1回, Type-III 症例0.3回と有意差を認め $(\mathrm{p}<0.01)$, 予想外の結果であった．その理由は説明がつかず，今 後の更なる検討が必要であると思われた。一方従来法 は疼痛が強く，入院期間も長い傾向にあった。特に Type-III でその傾向は強く, tension repair の短所が
強調されていると考えられた．鼠径管後壁の正常な Type-I, II では入院期間に術式間の差を認めるものの 三術式とも短縮し，従来法でも鎮痛郕使用は少なかっ た.すなわち Type-I, II の従来法は tension repair と いっても鼠径管後壁に欠損がないため tensionのかか らない補強になったと考えられた。この点は，従来よ り Bassini 法等の後壁補強術式が Type-II を含めた全 ての鼠径ヘルニア手術の適応となっていたことが妥当 であり，必ずしも過剩な手術ではないと考えられた。

同じ tension free repair である Plug 法と鏡視下法 の鎮痛剤使用は有意差をもってPlug 法が少なかっ た. 術式の相違からは腹膜别離を行う鏡視下法に疼痛 を生じやすいと推測され，别離範囲の広い鏡視下法両 側例の平均鎮痛㓮使用回数 (1.9回) は片側例 (1.5回) よりも多かったが有意差は認められなかった。この Plug 法と鏡視下法の疼痛の差は術式以外に麻酔法や 気腹操作に依存するとも考えられ，今後更なる検討が 必要と思われた。

Mesh を使用することによる弊害として感染, 異物 感等があるが，自験例では経験がなく他の報告をみて も比較的稀な合併症と考えられた ${ }^{8 / 14116)}$. しかし一度生 じると Mesh 除去を余儀なくされる合併症であり、こ の短所を見逃すことはできない.またわれわれはPlug 法では全例既製のセットを使用しておりりここの plug は 直径 $4.8 \mathrm{~cm}$ (large size), preshaped onlay patch は $4.2 \times 8.9 \mathrm{~cm}$ と小さく，大きなへルニア門や大きな後 壁欠損には不向きである。われわれは大きなへルニア に対する Plug 法で手術不成功を 1 列経験したことよ 
り，大きな後壁補強を要するへルニアには大きな Mesh $(13 \times 8 \mathrm{~cm})$ を使用できる鏡視下法を行うか, 鏡 視下法に習熟していない施設や術者の場合は Plug 法 でも既製品を使用せずヘルニアの大きさに合った mesh と plug を自作すべきと考えている ${ }^{8)}$. な抢 Plug 法の内, 外鼠径ヘルニアに対する標準術式では大腿輪 の補強は行われていない(8)17)のに対し，鏡視下法が優 れているのは内鼠径輪, Hesselbach 三角, 大腿輪の 3 カ所のヘルニア発生部位を同時に 1 枚の Mesh で修復 できることである ${ }^{91012118) . ~}$

以上より各術式の特徴をまとめると, 従来法は手技 が容易だがへルニアの形態によっては疼痛を生じやす い, Plug 法は手技が容易で疼痛も少ないが, Mesh 使 用による合併症の可能性があり，また Mesh が小さい ため巨大へルニアには向かない，鏡視下法は大きな

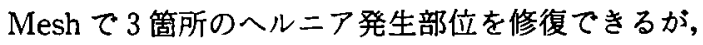
手術手技に修練を要し時間もかかる,といずれの術式 にも長所短所を認めた。

成人の鼠径ヘルニア手術の要点はヘルニア襄の処 理, ヘルニア門の縫縮閉鎖, 後壁補強の 3 点であり, Type-II I ではこれらの一部を省略することができ る.これらを満たす術式として Bassini 原法”が報告さ れてから100年以上経過した。 その間, McVay 法五, Iliopubic tract repair 法7)等多数報告されてきたが,こ れらの基本は Bassini 法と同様であった。近年になり 後壁補強に prosthesis を用いた tension free repair の概念が広まり，これを従来法と同椂の anterior approach で行う方法 ${ }^{19}$, preperitoneal approach で行 う方法 ${ }^{20221)}$ ，そして腹整鏡を用いて transabdominal preperitoneal approachて行う方法 ${ }^{499}$, extraperitoneal preperitoneal approach で行う方法 ${ }^{10}$ が報告 された. tension free repair は歴史も浅く本邦ではま だ標準術式になったとは言いがたいが, 従来からの tension repair と比較を行いその有用性は報告されて お汸 ${ }^{812) 191}$, 将来の標準術式となる可能性は高い. しか しこれらの報告は単純にふたつあるいは複数の術式間 の成績を比較しているにすぎず,ヘルニアの病態に応 じた比較はされていない. 例えれば stage-I の胃癌と stage-IV の胃癌の手術成績を一緒にするのと同じこ とである.

ヘルニアの病態を最も忠実単純に表現するものは Nyhus 分類 ${ }^{5)}$ と考えられ, 村田と出月 ${ }^{22)}$, 長町ら ${ }^{23)}$ は Nyhus 分類に応じた術式選択を行っているが，ヘルニ アの Type 別成績による毫付けはなかった。 大不ら
は 6 術式の成績から Nyhus 分類に従った治療計画を 考案し, Type-II には Marcy 法 ${ }^{25)}$, Type-III には Lichtenstein 法 ${ }^{19)}$ を適応とした. しかし, Type 別成績評価 はされておらず，この論文中の成績のみから治療計画 を導き出すには多少の無理があると考えられた。すな わちわれわれは Marcy法を行わずに Bassini 法など の tension repair を選択したが, Type-IIにおけるわ れわれの成績からは tension repairも適応として良い と考えられた。 また大梳ら 9 例の鏡視下法の経験か ら, 同法には QOL, 安全性の観点より有用性がなかっ たとしている．われわれの成績は，鏡視下手術に習熟 した術者が85例と比較的多数の鏡視下法を行った結果 から, 大木らの示すほど合併症は多くなく, 疼痛等の 点からも鏡視下法には一定の有用性が認められた.わ れわれの成縝を見る限り, 今後へルニアの成績につい て論じる場合は, Nyhus 分類をはじめとした病態別に その成績を述べることが必須になると思われた。

われわれは Nyhus 分類に従った各術式の成績から, 病態に応じた標準術式選択法を考案した。なおわれわ れが採用していない術式は多数あるが，手技に習熟し ていない術式では本来の目的に到達できないばかり か, 合併症を引き起こす要因となるため, 安全確実な 手術として採用できるもののなかから術式を選択し た。従ってこの術式選択法は全ての外科施設に共通す るものではなく，施設ごとの修正は必要である.

術式決定は次のように行う(図 3). すなわち, 両側 例と従来法での再発例はすでに鏡視下法の良い適応と 認識されており，この術式を行う ${ }^{14)(8)}$. 初発, 片側例で はまず Type-I は Mesh 挿入による補強の必要はな く，小児の術式と同様か修復を行ったとしても念のた めに行う僅かな補強, 縫縮で良いため, 従来法の中か ら適切なものを選ぶ. 自験例では成人の Type-I 症例 が少なく比較検討できていないが，小児と同じ Potts 法も適応となりうる. Type-II では術式間の較差が比 較的少なく tension repairでも疼痛が少ないため，患 者の年齢, QOL や将来性を考慮して術式を選択する. 明らかな Type-II は若年者に多く，人工物の使用をた めらう場合は従来法を行う。われわれは Marcy 法を 採用していないが, 自験例の疼痛に関する成績からは, 同法を含めていずれでも良いと考えられた. Type-II でも肉体労働者や若年で常に腹压がかかる活動をする 症例, 初診時の視触診で II とIIIの鑑別が困難な症例, Type-III への移行の可能性がある症例に遭遇するこ とがあり、このような場合は可能な限り III と同様に 
Mesh で後壁補強を行う. Type-III は全例 Mesh によ る補強の適応である。当科では Plug 法の成績が良好 で第一選択となりうるが，ヘルニアの大きさによって 必要な Mesh size が決まり，大きなへルニアには鏡視 下法が適切と考えられる。なお Type-IVであっても腹 腔鏡下法後の再発に対しては，今後の更なる検討が必 要と思われる。また嵌頓等の緊急症例はこの限りでな く,生命の安全を第一にして術式を決定すべきである. 病態別術式選択法を採用する以前の前期症例と, 採 用してからの後期症例の比較ては(表 4), 前期症例で は成績は悪い傾向にあり，Type-III に対する従来法な どの不適切な術式が行われていたためと考えられた。 後期症例では Type-III 症例をはじめとして適切な術 式が選ばれたため成績も向上したと考えられた。

\section{結語}

自験例における成人鼠径へルニア手術の成績につい て検討した結果, 各術式はいずれも長所短所を有し, 唯一最良の術式というものは確立されていないことが 再認識された。従って, 外科医は各術式に習熟し, 人 ルニアの病態や, 㭧者の QOL に合わせて症例ごとに 術式を選択すべきである．本論文では短期的中期的な 成績をもとに検討したが，今後は長期に渡る再発の有 無やQOL を加味して, 再検討する必要があると思わ れた.

なお，本論文の要旨は第59回日本臨床外科医学会総会(大 阪）において発表した。

\section{文 献}

1) Bassini E: Sulla cura radicale dill'ernia inguinale. Arch Soc Ital Chir $4: 380,1887$

2) Usher FC, Hill JR, Ochsner JL: Harnia repair with marlex mesh. Surgery $46: 718-724,1959$

3) Lichtenstein IL, Shore JM: Simplified repair of femoral and recurrent inguinal hernias by a "Plug" technic. Am J Surg 128 : 439-444, 1974

4) Ger R, Monroe K, Duvivier R, et al : management of indirect inguinal hernias by laparoscopic closure of the neck of the sac. Am J Surg $159: 370-373,1990$

5) Nyhus LK, Klein SM, Rogers FB: Inguinal hernia. Curr Probl Surg 18: 403-450, 1991

6) McVay CB : Inguinal and femoral hernioplasty, anatomic repair. Arch Surg $57: 524-530$, 1948

7) Condon RE: Anterior iliopubic tract repair. Hernia; Nyhus LM and Condon RE ed, JB
Lippincott Co, (Nyhus LM and Condon RE: Hernia 2nd ed, Philadelphia, Lippincott, 1978), 1978, p195-211

8) Rutkow IM, Robbins AW: "Tension-free" inguinal herniarrhaphy : A preliminary report on the "mesh plug" technique. Surgery $114: 3-8$, 1993

9) Salerno GM, Fitzgibbons RJ, Corbitt JD, et al : Laparoscopic inguinal hernia repair. Surgical Laporoscopy Update ; Zucker KA ed., Quality Medical Publishing, 1993, p373-394

10) McKernan JB, Laws HL : Laparoscopic repair of inguinal hernias using a totally extraperitoneal prosthetic approach. Surg Endosc 7: 26 $-28,1993$

11）枅瀨信太郎, 牧瀨永城：臼径へルニアと大腿へル ニア. 新外科学体系, 腹壁, 腹膜, イレウスの外科. 25B, 中山書店, 東京, 1990, p24-91

12）中村泰三, 吉田雅行, 小林利彦他: 腹腔鏡下へルニ ア修復術 適応とその限界. 外科診療 $37: 437-$ 443, 1995

13) Stoker PL, Spiegelhater DJ, Singh R, et al: Laparoscopic versus open inguinal hernia repair: Randomised prospective trial. Lancet 343 : 1243-1245, 1994

14) Brooks DC: A prospective comparison of laparoscopic and tension free open herniorrhaphy. Arch Surg 129: 361-366, 1994

15) Kavic MS: Laparoscopic hernia repair. Surg Endosc 7 : 163-167, 1993

16) Massaad AA, Fiorillo MA, Hallak A, et al: Endoscopic extraperitoneal herniorrhaphy in 316 patients. J Laparoendosc Surg 6: 13-16, 1996

17）平井淳一, 白就健朗：プラグ法によるへルニア修 復術. 手術 $49: 245-250,1995$

18) Felix EL, Michas CA, McKnight RL: Laparoscopic repair of recurrent groin hernias. Surg Laparosc Endosc 4: 200-204, 1994

19) Lichtenstein IL, Shulman AG, Amid PK, et al : The tension-free hernioplasty. Am J Surg 157: 188-193, 1989

20) Stoppa RE, Rives JL, Warlaumont CR, et al : The use of Dacron in the repair of hernias of the groin. Surg Clin North Am 64: 269-285, 1984 
21) Nyhus LM, Condon RE: Hernia, 3rd edition, Loppincott, Philadelphia, 1989, p154-225

22）村田宣夫, 出月康夫：成人の梟径ヘルニア手術の ポイント. 外科診療 $37: 405-410,1995$

23）長町幸雄, 寉田正幸, 野崎外茂次他：小児及び成人 鼠径ヘルニア手術の再検討. 日臨外医会誌 56 : 1999-2012, 1995
24) 大木隆生, 宮本 栄, 平山茂樹他：術後 QOL と安 全性から見た各種成人鼠径へルニア手術の検討. 日臨外医会誌 $57: 816-823,1996$

25) Marcy HO: The radical cure of hernia by the antiseptic use of the carbolize catgut ligature. Trans A Micro Soc $2: 295-305,1878$

\title{
SURGICAL PROCEDURE FOR GROIN HERNIAS SELECTED BY THE NYHUS' CLASSIFICATION
}

\author{
Maki MURAKAMI, Yasuhiro MUNAKATA, Ken HAYASHI, Hideki NISHIMURA, \\ Emi MACHIDA and Atsuyoshi MITA \\ Department of Surgery, Nagano Municipal Hospital
}

We have made a nonrandomaized study to compare operative procedure for groin hernias including open conventional, open mesh plug, and laparoscopic mesh hernia repair by types of hernias according to the Nyhus' classification. In type-I and II hernias, there were small difference in duration of postoperative hospital stay and frequency of narcotic analgesics among three procedures. In type-III, the conventional repair required longer postoperative hospital stay and more narcotic analgesics than the mesh plug or laparoscopic technique. Each procedure has both merits and demerits. We employ surgical procedure selected by the condition of hernia and the patient's quality of life. In type-I, the conventional technique is suitable for the patients who don't require repair with prosthetic material. In type-II, the conventional procedure without prosthesis may be the preferred repair in the young patient, while the tension free repair is proper for the hernia close to type-III. The mesh plug repair that turned out good results is indicated in type-III, but for large hernias, the laparoscopic technique that uses a large mesh offers an excellent repair. In type-IV, the laparoscopic repair is appropriate for recurrent hernias after anterior approach. This approach that operative procedure is selected by the Nyhus' classification has produced good postoperative results. 